\title{
Comparison ability of algae and nanoparticles on nitrate and phosphate removal from aquaculture wastewater
}

\author{
Majid Askari Hesni ${ }^{12^{*} \oplus}$, Seyed Aliakbar Hedayati ${ }^{3^{\circledR}}$, Amir Qadermarzi ${ }^{3^{\circledR}}$, Mojtaba Pouladi ${ }^{3^{\circledR}}$, Somayeh \\ Zangiabadi $^{4}$, Nabat Naqshbandi ${ }^{5}$ \\ ${ }^{1}$ Research and Technology Institute of Plant Production, Shahid Bahonar University of Kerman, Kerman, Iran \\ ${ }^{2}$ Department of Biology, Faculty of Sciences, Shahid Bahonar University of Kerman, Kerman, Iran \\ ${ }^{3}$ Department of Aquatic Production and Exploitation, Faculty of Fisheries and Environmental Sciences, Gorgan University of \\ Agricultural Sciences and Natural Resources, Gorgan, Iran \\ ${ }^{4}$ Department of Plant Biology, Faculty of Biological Sciences, Tarbiat Modares University, Tehran, Iran \\ ${ }^{5}$ Department of Biology, Faculty of Sciences, Payame Noor University, Oshnavieh, West Azarbaijan, Iran
}

\begin{abstract}
Background: Aquaculture wastewater contains high levels of phosphate and nitrate. The reuse of this water requires standards beyond the secondary standards to eliminate more organic pollutants from aquaculture effluents. In this research, the removal of these pollutants from wastewater using Chlorella vulgaris and $\mathrm{Fe}_{3} \mathrm{O}_{4}$ nanoparticles in the reactor space was investigated.

Methods: This study was conducted on fish farms effluent in the laboratory system. For this purpose, a 5-L semi-industrial reactor with a mixer blade, porous plate, and a compressor was designed. Chlorella vulgaris samples were collected from the natural environment and cultured in the laboratory environment. Also, $\mathrm{Fe}_{3} \mathrm{O}_{4}$ nanoparticles were prepared from Iranian Nano Pishgaman Company to make the desired solution. During the experiment (3 weeks), samples were taken weekly (in one phase) from the effluent. Dissolved oxygen (DO), $\mathrm{pH}$, nitrate $\left(\mathrm{NO}_{3}\right)$, and phosphate $\left(\mathrm{PO}_{4}\right)$ factors from the influent and effluent of the farms were measured. The statistical data were analyzed using SPSS version 21 and Excel 2013.

Results: The amounts of nitrate and phosphate were decreased by about 80.76 and $80.55 \%$ in the biological reactor, whereas these amounts were 70.52 and $70.48 \%$ in the nanoparticle reactor, respectively. Also, there were significant differences in the amounts of $\mathrm{NO}_{3}$ and $\mathrm{PO}_{4}$ between the control treatment and weekly treatment $(P<0.05)$.

Conclusion: Based on the results, both reactors were able to reduce nitrate and phosphate from aquaculture wastewater, but the efficiency of the biological reactor was higher than that of the nanoparticle reactor. Keywords: Nitrate, Phosphate, $\mathrm{Fe}_{3} \mathrm{O}_{4}$ nanoparticle, Chlorella vulgaris, Biological refinement Citation: Askari Hesni M, Hedayati SA, Qadermarzi A, Pouladi M, Zangiabadi S, Naqshbandi N. Comparison ability of algae and nanoparticles on nitrate and phosphate removal from aquaculture wastewater. Environmental Health Engineering and Management Journal 2019; 6(3): 171-177. doi: 10.15171/EHEM.2019.19.
\end{abstract}

\section{Article History:}

Received: 9 February 2019

Accepted: 11 May 2019

ePublished: 1 August 2019

\author{
*Correspondence to: \\ Majid Askari Hesni \\ Email:mahesni@gmail.com
}

\section{Introduction}

Sewage production has been grown dramatically with increasing population growth, water consumption, and industrial development. The discharge of sewage causes environmental degradation, contamination of surface waters and underground resources, and the occurrence of acute and chronic diseases $(1,2)$. Nitrogen and phosphate are essential elements for plants and living organisms. Nonetheless, the entry of nitrogen and nitrogen from agricultural land, untreated municipal, and industrial wastewaters into the water can be one of the most important sources threatening water quality (3). Algae have the ability to absorb nitrogen and phosphate nutrients for photosynthesis, pigment and protein production. Algae are capable of absorption of nutrients even at low concentrations due to resistance to temperature and $\mathrm{pH}$ changes. Also, algae have simple and inexpensive production technology (4). The excessive growth of the aquaculture industry through the excessive use of natural resources has disrupted natural balance. The aquaculture effluents can be as a source of pollution in the environment (5).

The studies have shown that low levels of nitrogen (about $0.4 \mathrm{mg} \mathrm{\textrm {L } ^ { - 1 }}$ ) and phosphorus (about $0.1 \mathrm{mg} \mathrm{L}^{-1}$ ) in calm waters (i.e., swamps and lakes) cause rapid growth of algae $(6,7)$. Therefore, their growth reduces the concentration 
of dissolved oxygen and the penetration of light into the water, which leads to the destruction of fish and microorganisms. By the death of these organisms, the oxygen demand for their decomposition increases. In these conditions, the aerobic environment becomes anaerobic and all of these processes lead to water enrichment. In addition to the problems caused by this phenomenon for the environment, the process of purifying these waters is costly and undesirable $(6,7)$. Drinking Nitratecontaminated water causes children's blood diseases and adults' gastro-intestinal cancers. Therefore, the level of phosphate and nitrogen must be reduced prior to the discharge of effluent into the aquatic environments (8). There is a wide range of sewage treatment systems that often have some limitations, such as high cost and high energy consumption, which often require complex maintenance and operation but also have high efficiency, including biodegradation (9).

Nowadays, nanoparticles are also used to remove pollutants. Various studies have suggested the effectiveness of this method in removing pollutants such as heavy metal cations and nitrate compounds (10). There are various physical, chemical, and biological methods to reduce the amount of effluents from the aquaculture in the environment and soil (11). A lot of studies have been done to determine the effect of aquaculture wastewaters on the environment and also to find pollution control ways (12-17). Although physical and chemical methods may be effective, these methods are costly and do not result in complete decomposition or complete destruction of the contaminants. In the biodegradation method, pollutants are consumed by micro-algae as food and turned into biological cells or living masses, and finally, are removed from the environment. Due to the problems caused by phosphates, nitrates, and other pollutants in the drinking waters and the enrichment of water resources, the aim of this study was to reduce the nutrients of aquaculture effluents discharged in the environment using biological and nanoparticle reactors in the laboratory environment.

\section{Materials and Methods}

\section{Microalgal culture}

Chlorella vulgaris samples were collected from the natural environment and cultured under laboratory conditions. The continuous light and temperature were $50 \mu \mathrm{mol}$ photons $\mathrm{m}^{-2} \mathrm{~s}^{-1}$ and $25^{\circ} \mathrm{C}$, respectively. An artificial culture environment was used to cultivate algae. The artificial culture environment contained $\mathrm{NaNO}_{3}, \mathrm{CaCl}_{2} .2 \mathrm{H}_{2} \mathrm{O}$ (2.94 mM), $\mathrm{MgSO}_{4} .7 \mathrm{H}_{2} \mathrm{O}(0.05 \mathrm{mM}), \mathrm{K}_{2} \mathrm{HPO}_{4}(0.30 \mathrm{mM})$, $\mathrm{KH}_{2} \mathrm{PO}_{4}(0.17 \mathrm{mM}), \mathrm{NaCl}(0.43 \mathrm{mM})$, and $\mathrm{CaCO}_{3}(1.29$ $\mathrm{mM})$. Other micronutrients were prepared according to the BG11 culture medium (18). C. vulgaris was cultured in a volume of $100 \mathrm{~mL}$ in a $250 \mathrm{ml}$ Erlenmeyer in a micronutrient-enriched artificial culture environment. The algae cultivation was continued for 10 days. The required light was supplied with a high radiation fluorescent lamp and the cultures were stirred at a speed of $150 \mathrm{rpm}$. The light was measured and adjusted using a 1339 Lux meter. This method was continued to provide a suitable density and volume of the algae stoke. Then, the algae were added to the reactor space containing wastewater from fish farms.

\section{Preparation of iron oxide nanoparticles stock}

Iron oxide nanoparticle (NPs, with a diameter of $40 \mathrm{~nm}$, purity of 99\%, US Research Nanomaterials, Inc) was prepared from Iranian Nano Pishgaman Company to make a favorite solution. The nanoparticles were dispersed for 40 minutes using an ultrasound machine with a stirring rate of $400 \mathrm{rpm}$ in the distilled water $(250 \mathrm{cc})$ to homogenize. Since iron nanoparticles may be deposited on the bottom of the reactor, a stirrer engine was used to disperse nanoparticles in the water environment. Also, the water samples were tested by dynamic light scattering (DLS) technique to determine the dispersion rate of nanoparticles in the mixing tank.

\section{Preparation of wastewater samples}

All wastewater samples were collected from the fish farms of Shahid Rajai center located in the suburb of Sari city ( $36^{\circ} 37^{\prime} 0$ ” N, 538 ' 58” E), Mazandaran province. The main target of this center is the production of the fish larva (bony fish and sturgeon larvae) for the sustainable development of aquatic animals.

\section{Reactor design}

To design a semi-industrial reactor in an unconstrained mode, the reactor volume was optionally set at $5 \mathrm{~L}$ and design calculations were performed (Figure 1). The reactor can be designed according to the standard dimensions for reservoir reactors (19).

Proportions in the construction of the reactor dimensions were $\left(\mathrm{D}=\mathrm{H}_{\mathrm{L}}\right),\left(\mathrm{d}=\mathrm{H}_{\mathrm{i}}\right),(\mathrm{d} / \mathrm{D}=1 / 3),(\mathrm{L} / \mathrm{d}=1 / 4)$, and $(\mathrm{b} / \mathrm{d}$ $=1 / 5)$. According to the present standard, the dimensions of a $5 \mathrm{~L}$ semi-industrial reactor would be as follows: $\left(\mathrm{H}_{\mathrm{L}}=\right.$ $20.5 \mathrm{~cm}),\left(\mathrm{D}=\mathrm{H}_{\mathrm{L}}=20.5 \mathrm{~cm}\right),\left(\mathrm{d}=\mathrm{H}_{\mathrm{i}}=6.83 \mathrm{~cm}\right),(\mathrm{b}=1$. $366 \mathrm{~cm}),(\mathrm{L}=1.7 \mathrm{~cm})$, and $\left(\mathrm{W}_{\mathrm{b}}=1.43 \mathrm{~cm}\right)$.

The mixer used for designed reactor

Homogenization of nanoparticles and algae was performed

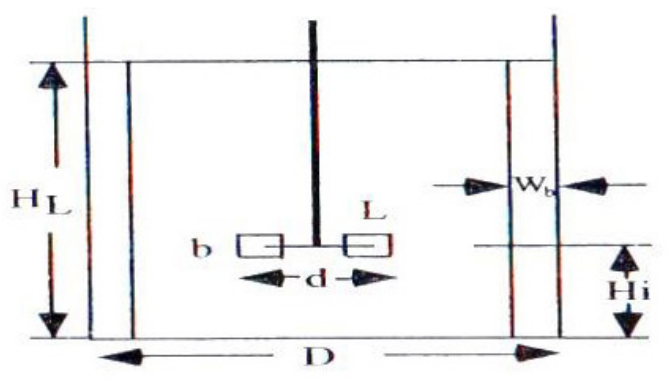

Figure 1. Standard dimensions of reservoir reactor (19). 
using a homogenizer with a speed of $14000 \mathrm{rpm}$ in the laboratory. In order to provide suitable conditions for the 5-liter bioreactor, the mixer was designed as a turbine and its dimensions are presented in Figure 2.

According to the requirements of the reaction, the standard for the reactor, and blade dimensions, the ratio of blade diameter to the turbine blade tank diameter is 0.3 to 0.5 (20). Therefore, a suitable blade was selected for the turbine of the designed bioreactor. The required power was the most important parameter for the designed mixer, which was calculated using Eq. 1 (21):

$\mathrm{P}_{\mathrm{A}}=\mathrm{P}_{0} \rho \mathrm{N}^{3} \mathrm{D}_{\mathrm{A}}^{5}$

where $P_{0}$ is the air column pressure, $\rho$ is density, $N$ is the length of flow, $D$ is the depth of flow, and $\mu$ is the viscosity of flow. $\mathrm{P}_{0}$ was calculated by the mixing Reynolds number. The Reynolds number was calculated using Eq. 2 (21):

$$
\operatorname{Re}_{\mathrm{M}}=\frac{\rho \mathrm{ND}_{\mathrm{A}}^{2}}{\mu}=\frac{\left(1000 \times 2.167 \times\left(0.0683^{2}\right)\right)}{0.1}=101.09
$$

In order to prevent the nanoparticles deposition at the bottom of the reactor, a porous plate with an air inlet is required to create turbulence in the reservoir (Figure 3). Therefore, the air was transferred to the lower surface of the reactor using a compressor (by a tube with a diameter of $1 / 8$ inch) (Figure).

The fluid pressure inside the bioreactor was calculated using Eq. 3 (21):

$P=\rho g h+p_{0}=1000 \times 9.8 \times 0.1435 / 101325+1=1.014 \mathrm{~atm}$

where $P_{0}$ is the air column pressure, $\rho$ is density, $G$ is the gravitational acceleration, and $h$ is the liquid column height.

Nitrate and phosphate were measured by a Nanocolor spectrophotometer (UV-Vis Spec, Germany). Also, $\mathrm{pH}$ and DO parameters were measured by the $780 \mathrm{pH}$ Meter (Metrohm, Sweden) and D.O. meter (AZ8403), respectively (22). The statistical data were analyzed using SPSS version 21 and Excel 2013.

\section{Results}

The amounts (mean $\pm \mathrm{SE}$ ) of $\mathrm{NO}_{3}, \mathrm{PO}_{4}, \mathrm{DO}$, and $\mathrm{pH}$ measured during the experiment for nanoparticle and biological reactors are presented in Tables 1 and 2, respectively. In the nanoparticle reactor, the concentration of nitrate was $48.61 \pm 7.2 \mathrm{mg} \mathrm{L}^{-1}$ in the control treatment but it was decreased to $16.01 \pm 9.6 \mathrm{mg} \mathrm{L}^{-1}$ after three weeks. Also, the concentration of phosphate in the control treatment was $8.52 \pm 1.27 \mathrm{mg} \mathrm{L}^{-1}$ but it was decreased to $2.86 \pm 0.47 \mathrm{mg} \mathrm{L}^{-1}$ after three weeks. The amounts of DO and $\mathrm{pH}$ in the control treatment were $5.17 \pm 2.18 \mathrm{mg} \mathrm{L}^{-1}$ and $8.69 \pm 0.1$ treatment, respectively, while these amounts decreased to $4.83 \pm 1.62 \mathrm{mg} \mathrm{L}^{-1}$ and $8.73 \pm 0.19$ in the third week of treatment, respectively. There were significant

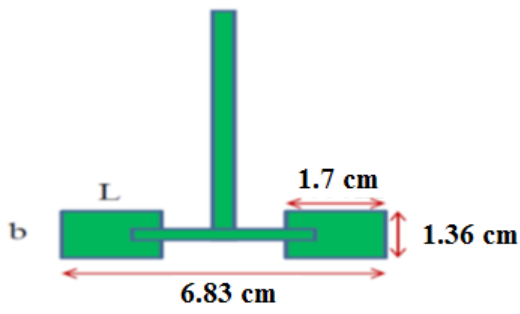

Figure 2. Schematic of the designed mixer in the reactor.

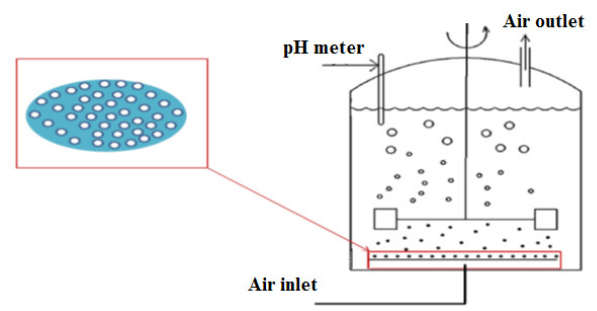

Figure 3. A schematic of air injection to the bioreactor and penetration in the fluid.

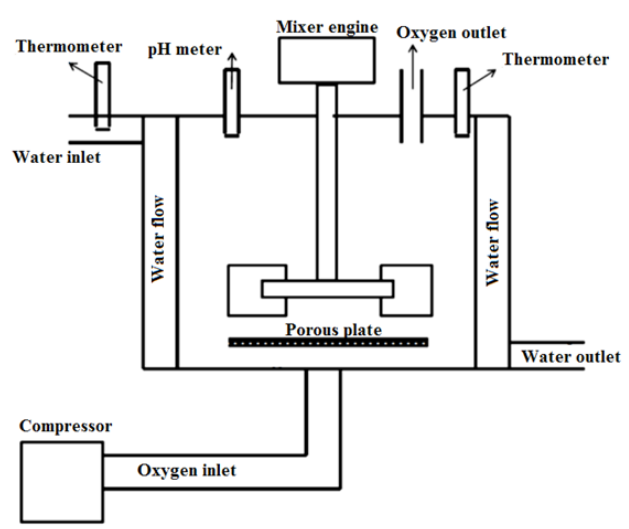

Figure 4. A complete schematic of the designed reactor.

differences in the amounts of $\mathrm{NO}_{3}, \mathrm{PO}_{4}$, and $\mathrm{DO}$ between the control treatment and weekly treatments $(P<0.05)$ (Table 1).

In the biological reactor, the amount of nitrate in the control treatment was $48.61 \pm 7.2 \mathrm{mg} \mathrm{L}^{-1}$ but it was decreased to $24.53 \pm 5.61 \mathrm{mg} \mathrm{L}^{-1}$ after three weeks. Also, the amount of phosphate in the control treatment was $8.52 \pm 1.27 \mathrm{mg} \mathrm{L}^{-1}$ but it was decreased to $4.34 \pm 0.39 \mathrm{mg} \mathrm{L}^{-1}$ after three weeks. The amounts of $\mathrm{DO}$ and $\mathrm{pH}$ in the control treatment were $5.17 \pm 2.18 \mathrm{mg} \mathrm{L}^{-1}$ and $8.69 \pm 0.1$ whereas these amounts decreased to $4.57 \pm 1.27 \mathrm{mg} \mathrm{L}^{-1}$ and $8.57 \pm 0.26$ after three weeks, respectively. There were significant differences in the amounts of $\mathrm{NO}_{3}, \mathrm{PO}_{4}$, and $\mathrm{DO}$ between the control treatment and weekly treatments $(P<0.05)$ (Table 2$)$.

The results of comparison of the nitrate and phosphate changes among wastewater inlet, control treatment, and weekly treatments in the nanoparticle and biological reactors are presented in Figures 5 and 6 . According to the 
Table 1. The measured amounts (mean \pm SE) of parameters in the inlet and outlet of the nanoparticle reactor during the experiment

\begin{tabular}{|c|c|c|c|c|c|}
\hline Parameter & Wastewater inlet & Outlet (First week) & Outlet (Second week) & Outlet (Third week) & Control treatment \\
\hline NO3 $\left(\mathrm{mg} \mathrm{L}^{-1}\right)$ & 83.2 & $21.43 \pm 9.9^{b}$ & $18.61 \pm 6.2^{c}$ & $16.01 \pm 9.6^{c}$ & $48.61 \pm 7.2^{\mathrm{a}}$ \\
\hline PO4 $\left(\mathrm{mg} \mathrm{L}^{-1}\right)$ & 14.7 & $3.21 \pm 0.42^{b}$ & $3.07 \pm 0.31^{b}$ & $2.86 \pm 0.47^{c}$ & $8.52 \pm 1.27^{\mathrm{a}}$ \\
\hline $\mathrm{DO}\left(\mathrm{mg} \mathrm{L}^{-1}\right)$ & 1.27 & $4.47 \pm 1.09^{b}$ & $4.61 \pm 1.07^{b}$ & $4.83 \pm 1.62^{b}$ & $5.17 \pm 2.18^{\mathrm{a}}$ \\
\hline $\mathrm{pH}$ & 7.58 & $8.51 \pm 0.1^{\mathrm{a}}$ & $8.58 \pm 0.11^{\mathrm{a}}$ & $8.73 \pm 0.19^{a}$ & $8.69 \pm 0.1^{\mathrm{a}}$ \\
\hline
\end{tabular}

The lowercase letters represent a significant difference between treatments $(P<0.05)$.

Table 2. The measured amounts (mean \pm SE) of parameters in the inlet and outlet of the biological reactor during the experiment

\begin{tabular}{|c|c|c|c|c|c|}
\hline Parameter & Wastewater inlet & Out let (First week) & Out let (Second week) & Out let (Third week) & Control treatment \\
\hline $\mathrm{NO}_{3}\left(\mathrm{mg} \mathrm{L}^{-1}\right)$ & 83.2 & $35.13 \pm 7.2^{b}$ & $28.91 \pm 3.42^{c}$ & $24.53 \pm 5.61^{d}$ & $48.61 \pm 7.2^{a}$ \\
\hline $\mathrm{PO}_{4}\left(\mathrm{mg} \mathrm{L}^{-1}\right)$ & 14.7 & $6.48 \pm 0.44^{b}$ & $4.92 \pm 0.11^{\mathrm{c}}$ & $4.34 \pm 0.39^{c}$ & $8.52 \pm 1.27^{\mathrm{a}}$ \\
\hline $\mathrm{DO}\left(\mathrm{mg} \mathrm{L}^{-1}\right)$ & 1.27 & $4.31 \pm 1.87^{b}$ & $4.47 \pm 1.53^{b}$ & $4.57 \pm 1.27^{b}$ & $5.17 \pm 2.18^{\mathrm{a}}$ \\
\hline $\mathrm{pH}$ & 7.58 & $8.53 \pm 0.19^{a}$ & $8.46 \pm 0.23^{\mathrm{a}}$ & $8.57 \pm 0.26^{a}$ & $8.69 \pm 0.1^{\mathrm{a}}$ \\
\hline
\end{tabular}

The lowercase letters represent a significant difference between treatments $(P<0.05)$.

obtained results in the nanoparticle reactor, the amounts of nitrate compared with inlet wastewaters were decreased about $74.25,77.64$, and $80.76 \%$ whereas these amounts were decreased about $57.78,65.26$, and $70.52 \%$ in the biological reactor during three weeks (Figure 5). Also, the amounts of phosphate in the nanoparticle reactor were decreased about $78.17,79.12$, and $80.55 \%$ while the amounts of phosphate were decreased about 55.92, 66.54, and $70.48 \%$ in the biological reactor (Figure 6).

The particle size of iron oxide nanoparticles solution in the nanoparticle reactor space is shown in Figure 7. Accordingly, $95 \%$ of the particles in the suspension solution were $85 \mathrm{~nm}$ in diameter, indicating that particles were not deposited on the bottom of the reactor tank.

\section{Discussion}

Nowadays, the quantity of available freshwater has been decreased. Also, water sources have been contaminated by the industrial activities and urbane wastewaters $(23,24)$. Pollution of water resources is one of the most important

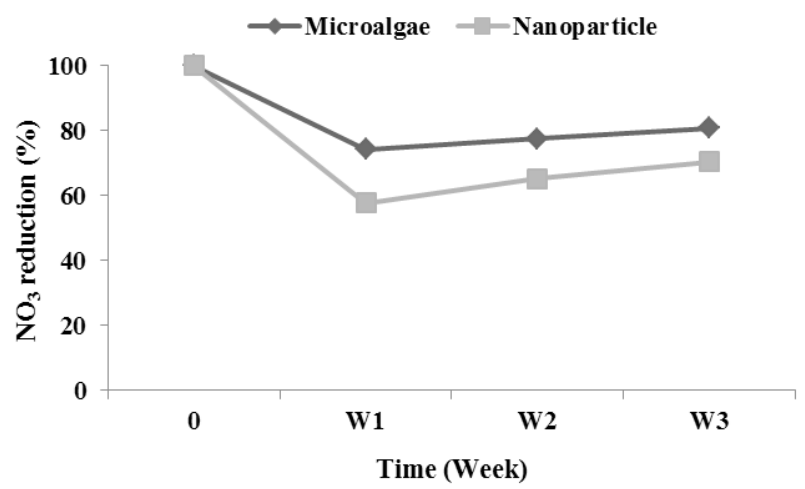

Figure 5. Comparison of the nitrate reduction using nanoparticle and biological reactors during the experiment. environmental problems in the world (25-27). Microalgae have the potential to eliminate inorganic nutrients such as phosphorus and nitrogen from wastewater, and hence, received significant consideration in the recent years (28). According to the results, the amounts of nitrate and phosphate were significantly decreased after three weeks

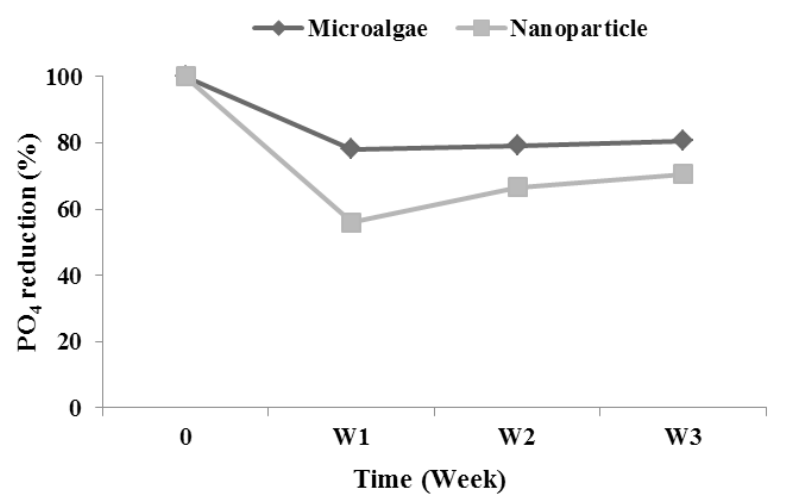

Figure 6. Comparison of the phosphate reduction using nanoparticle and biological reactors during the experiment.

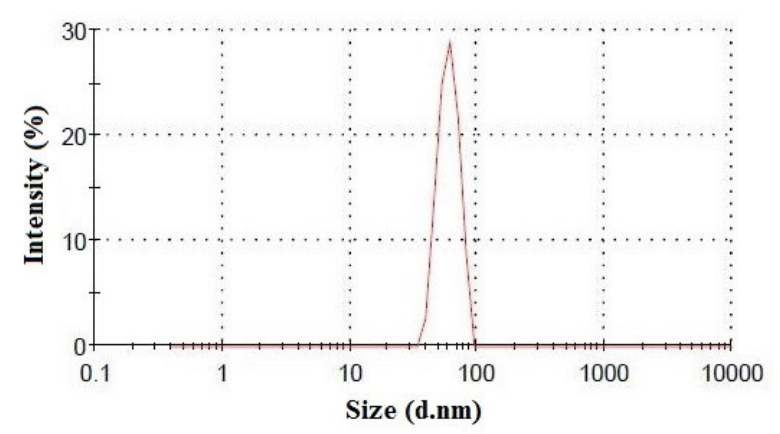

Figure 7. The particle size of iron oxide nanoparticles solution in the nanoparticle reactor. 
in the biological reactor (Table 1 and Figure 5). Therefore, the use of $C$. vulgaris was desirable in this study, which is consistent with the results of other studies (23,29-31). The advantage of using algae in wastewater treatment systems is the recycling of food and its consumption by algae, which reduces the probability of eutrophication and other ecological damages (32). Voltolina et al used Scenedesmus quadricauda to test the removal of ammonia and found that microalgae such as Scenedesmus can be used in breeding systems as an appropriate option for wastewater treatment due to high growth, simple and cost-effective technology (29). Zhang et al observed that S. quadricauda and C. vulgaris removed about $100 \%$ nitrogen, phosphorus, and ammonia at the final purification stage (30). The efficiency of algae in wastewater treatment depends on the type of species, algal mass volume, $\mathrm{pH}$, aeration, and time to maximize the activity of algae in the wastewater $(13,15)$. Tang et al investigated the reduction of nitrogen and phosphorus in effluents using spirulina and found that it needs phosphorus and nitrate in the culturing process and culturing of spirulina in wastewater could decrease nitrate content from $16 \pm 4.30$ to $5.5 \pm 1.50 \mathrm{ppm}$ (31). According to a study by Sayadi et al, the amounts of nitrate and phosphate removal by $C$. vulgaris and $S$. platensis were significant, therefore, these microalgae can be effectively used to remove nitrate and phosphate from wastewaters (23). In another study by Sabeti et al on the enhanced removal of nitrate and phosphate from wastewater by $C$. vulgaris (temperature $=26.3^{\circ} \mathrm{C}, \mathrm{pH}=8$, and aeration rate $=4.7 \mathrm{~L} \mathrm{~min}^{-1}$ ), approximately $85 \%$ of the total nitrate and $77 \%$ of the total phosphate were removed after 48 and 24 hours, respectively (33).

During the experiment, the reduction percentages of nitrate and phosphate were acceptable in the nanoparticle reactor, but the values were lower compared to those obtained from the biological reactor (Figures 5 and 6). Iron oxide nanoparticles with low harmfulness, chemical inertness, and biocompatibility show a significant potential in combination with biotechnology (34). The removal of nitrate using zero-valent iron nanoparticles is very desirable due to the simplicity of the system, rapid reaction, low cost, and high removal efficiency from the engineering and economic point of view (10). Chen et al examined the removal of nitrate by a fluid substrate containing iron nanoparticles and observed that the removal of nitrate ion under optimum conditions was 85\% (35). Malakootian et al reported that the Fenton process with zero-valent nanoparticles could be effective in reducing nitrate under optimum conditions during the process of absorbing $\mathrm{Fe} / \mathrm{H}_{2} \mathrm{O}_{2}$ in the removal of nitrate from water and could be used to remove similar compounds (36). The use of iron compounds at low $\mathrm{pH}$ levels in the presence of hydrogen peroxide can have a beneficial effect on the nitrate decomposition. This process can be used for the chemical reduction of nitrate in the contaminated groundwater (16). The study of Rafati et al on the removal of phosphate by iron nanoparticle resin, Lewatit (FO36), showed that the concentration of phosphate reached 1.6 $\mathrm{mg} \mathrm{g}^{-1}$ while the initial concentration of phosphate was 6 $\mathrm{mg} \mathrm{L}^{-1}$ (37). Bani Najjar showed that zero-valent iron can be used to remove nitrate due to its unique regenerative property, surface area, and high activity as a coating on the carbon substrate (38). Cao et al reported that the removal efficiency of phosphate using iron oxide nanoparticles synthesized by eucalyptus leaf extract in the presence of cetyltrimethylammonium bromide surfactant increased from $71.0 \%$ to $97.3 \%$ (39). Based on a study by Khodadadi et al. (2017), the powdered activated carbon sorbent coated with magnetic iron nanoparticles has a desirable capability in the removal of phosphate from aqueous environments (40).

\section{Conclusion}

Unrefined sewage can result in many environmental problems. The use of systems with low energy consumption will reduce the wastewater treatment, which can be appropriate for environmental management. According to the results, nitrate and phosphate levels in both reactors were significantly reduced compared to the control treatment. Also, the biological reactor was more effective in removing nitrate and phosphate than the nanoparticle reactor. Therefore, in order to increase the efficiency of wastewater removal, a simultaneous system of algae films and nanoparticles can be useful.

\section{Acknowledgments}

The authors are grateful to the Research and Technology Institute of Plant Production (RTIPP), Shahid Bahonar Kerman University, for their technical collaborations and financial support during the study period.

\section{Ethical issues}

The authors have thoroughly observed ethical issues and certify that no data from the study has been or will be published separately elsewhere.

\section{Competing interests}

The authors declared no competing interests.

\section{Authors' contributions}

All authors contributed in all aspects of this research like performing surveys and experiments, preparing the figures and tables, designing the experiments, analyzing the graphical data, writing the manuscript, and providing a critical revision of the paper.

\section{References}

1. Hosseini HR, Ghodsian M. Wetlands their benefits and disadvantages. 2nd Public Conference of Application Usage Researches; 2011 May 18-19. Zanjan: Zanjan Regional Water Company; 2011.

2. Baharvand F, Baharvand A, Hedayati SAA, Rezaie H. 
Possibility of using nano-iron enriched with nano-clay as urban wastewater nano-filter. Invertis Journal of Renewable Energy 2016; 6(2): 67-73. doi: 10.5958/24547611.2016.00008.4.

3. Chang H. Spatial analysis of water quality trends in the Han River basin, South Korea. Water Res 2008; 42(13): 3285304. doi: 10.1016/j.watres.2008.04.006.

4. Tsagkamilis P, Danielidis D, Dring MJ, Katsaros C. Removal of phosphate by the green seaweed Ulva lactuca in a smallscale sewage treatment plant (Ios Island, Aegean Sea, Greece). J Appl Phycol 2010; 22(3): 331-9. doi: 10.1007/ s10811-009-9463-4.

5. Naylor RL, Goldberg RJ, Mooney H, Beveridge M, Clay J, Folke C, et al. Natures subside to shrimp and salmon farming. Science 1998; 282(5390): 883-4. doi: 10.1126/ science.282.5390.883.

6. da Costa RA, Koening ML, de Macedo SJ. Urban secondary sewage: an alternative medium for the culture of Tetraselmis chuii (Prasinophyceae) and Dunaliella viridis (Chlorophyceae). Braz Arch Biol Technol 2004; 47(3): 4519. doi: 10.1590/S1516-89132004000300016.

7. Aslan S, Kapdan IK. Batch kinetics of nitrogen and phosphorus removal from synthetic wastewater by algae. Ecol Eng 2006; 28(1): 64-70. doi: 10.1016/j. ecoleng.2006.04.003.

8. Lin YF, Jing SR, Wang TW, Lee DY. Effects of macrophytes and external carbon sources on nitrate removal from groundwater in constructed wetlands. Environ Pollut 2002; 119(3): 413-20. doi: 10.1016/S0269-7491(01)00299-8.

9. von Sperling M. Comparison among the most frequently used systems for wastewater treatment in developing countries. Water Sci Technol 1996; 33(3): 59-72. doi: 10.1016/0273-1223(96)00301-0.

10. Bhatnagar A, Sillanpaa M. A review of emerging adsorbents for nitrate removal from water. Chem Eng J 2011; 168(2): 493-504. doi: 10.1016/j.cej.2011.01.103.

11. Juhasz AL, Naidu R. Bioremediation of high molecular weight polycyclic aromatic hydrocarbons: a review of the microbial degradation of benzo[a]pyrene. Int Biodeterior Biodegradation 2000; 45(1-2): 57-88. doi: 10.1016/S09648305(00)00052-4.

12. Preston N, Rothlisberg P, Burford M, Jackson C. The environmental management of shrimp farming in Australia. [cited 1 Feb 2019] Available from: https://enaca. org $/$ ? id $=528$.

13. Marinho-Soriano E, Nunes SO, Carneiro MA, Pereira DC. Nutrients' removal from aquaculture wastewater using the macroalgae Gracilaria birdiae. Biomass Bioenergy 2009; 33(2): 327-31. doi: 10.1016/j.biombioe.2008.07.002.

14. Guo Z, Liu Y, Guo H, Yan S, Mu J. Microalgae cultivation using an aquaculture wastewater as growth medium for biomass and biofuel production. Journal of Environmental Sciences 2013; 25(Suppl 1): S85-8. doi: 10.1016/s10010742(14)60632-x.

15. Van Den Hende S, Beelen V, Bore G, Boon N, Vervaeren H. Up-scaling aquaculture wastewater treatment by microalgal bacterial flocs: from lab reactors to an outdoor raceway pond. Bioresour Technol 2014; 159: 342-54. doi: 10.1016/j. biortech.2014.02.113.

16. Karimi B, Rajaei MS, koulivand A, Darvishi Cheshmeh
Soltani R. Performance evaluation of advanced $\mathrm{Fe} / \mathrm{Fe}+2 /$ $\mathrm{Fe}+3 / \mathrm{H} 2 \mathrm{O} 2$ process in the reduction of nitrate and organic matter from aqueous solution. Desalin Water Treat 2014; 52(31-33): 6240-8. doi: 10.1080/19443994.2013.817631.

17. Grote B. Bioremediation of aquaculture wastewater: evaluating the prospects of the red alga Palmaria palmata (Rhodophyta) for nitrogen uptake. J Appl Phycol 2016; 28(5): 3075-82. doi: 10.1007/s10811-016-0848-x.

18. Ilavarasi A, Mubarakali D, Praveenkumar R, Baldev E, Thajuddin N. Optimization of various growth media to freshwater microalgae for biomass production. Biotechnology (Faisalabad) 2011; 10(6): 540-5. doi: 10.3923/biotech.2011.540.545.

19. Katoh S, Horiuchi JI, Yoshida F. Biochemical Engineering: A Textbook for Engineers, Chemists and Biologists. US: John Wiley \& Sons; 2015.

20. Joulaei F. Simulation of Computational Fluid Dynamics of Mixture Bioreactors in the enzymatic production of Hydrogen Peroxide [dissertation]. East Azarbaijan: Science and Research Branch of Islamic Azad University; 2011.

21. Holland FA, Bragg R. Fluid Flow for Chemical Engineers. London: Edward Arnold; 1995. p. 174-81.

22. American Public Health Association, American Water Works Association. Standard Methods for the Examination of Water and Wastewater. Washington, DC: APHA, AWWA, WEF; 1999.

23. Sayadi MH, Ahmadpour N, Fallahi Capoorchali M, Rezaei MR. Removal of nitrate and phosphate from aqueous solutions by microalgae: an experimental study. Global Journal of Environmental Science and Management 2016; 2(4): 357-64. doi: 10.22034/gjesm.2016.02.04.005.

24. Abhijna UG. Monitoring and assessment of a eutrophicated coastal lake using multivariate approaches. Global Journal of Environmental Science and Management 2016; 2(3): 275-88. doi: 10.7508/gjesm.2016.03.007.

25. Stone V, Nowack B, Baun A, van den Brink N, Kammer FV, Dusinska $M$, et al. Nanomaterials for environmental studies: classification, reference material issues, and strategies for physico-chemical characterisation. Sci Total Environ 2010; 408(7): 1745-54. doi: 10.1016/j.scitotenv.2009.10.035.

26. Kizılkaya B, Turker G, Akgul R, Dogan F. Comparative Study of Biosorption of Heavy Metals Using Living Green Algae Scenedesmus quadricauda and Neochloris pseudoalveolaris: Equilibrium and Kinetics. J Dispers Sci Technol 2012; 33(3): 410-9. doi: 10.1080/01932691.2011.567181.

27. Rezaei A, Sayadi MH. Long-term evolution of the composition of surface water from the River Gharasoo, Iran: a case study using multivariate statistical techniques. Environ Geochem Health 2015; 37(2): 251-61. doi: 10.1007/ s10653-014-9643-2.

28. Khan M, Yoshida N. Effect of L-glutamic acid on the growth and ammonium removal from ammonium solution and natural wastewater by Chlorella vulgaris NTM06. Bioresour Technol 2008; 99(3): 575-82. doi: 10.1016/j. biortech.2006.12.031.

29. Anderson RC, Mather JA, Steele CW. Burying and associated behaviors of Rossia pacifica (Cephalopoda: Sepiolidae). Vie Milieu 2004; 54(1): 13-19.

30. Zhang E, Wang B, Wang Q, Zhang S, Zhao B. Ammonianitrogen and orthophosphate removal by immobilized 
Scenedesmus sp. isolated from municipal wastewater for potential use in tertiary treatment. Bioresour Technol 2008; 99(9): 3787-93. doi: 10.1016/j.biortech.2007.07.011.

31. Tang D, Han W, Li P, Miao X, Zhong J. CO2 biofixation and fatty acid composition of Scenedesmus obliquus and Chlorella pyrenoidosa in response to different CO2 levels. Bioresour Technol 2011; 102(3): 3071-6. doi: 10.1016/j. biortech.2010.10.047.

32. Hammouda O, Gaber A, Abdelraouf N. Microalgae and wastewater treatment. Ecotoxicol Environ Saf 1995; 31(3): 205-10. doi: 10.1006/eesa.1995.1064.

33. Sabeti MB, Hejazi MA, Karimi A. Enhanced removal of nitrate and phosphate from wastewater by Chlorella vulgaris: Multi-objective optimization and CFD simulation. Chin J Chem Eng 2019; 27(3): 639-48. doi: 10.1016/j. cjche.2018.05.010.

34. Gupta AK, Gupta M. Synthesis and surface engineering of iron oxide nanoparticles for biomedical applications. Biomaterials 2005; 26(18): 3995-4021. doi: 10.1016/j. biomaterials.2004.10.012.

35. Chen YM, Li CW, Chen SS. Fluidized zero valent iron bed reactor for nitrate removal. Chemosphere 2005; 59(6): 753 -
9. doi: 10.1016/j.chemosphere.2004.11.020.

36. Malakootian $\mathrm{M}$, Yaghmaian $\mathrm{K}$, Tahergorabi $\mathrm{M}$. The efficiency of nitrate removal in drinking water using iron nano-particle: determination of optimum conditions. Toloo-E-Behdasht 2011; 10(2): 35-44. [In Persian].

37. Rafati L, Nabizadeh R, Mahvi AH, Dehghani MH. Removal of phosphate from aqueous solutions by iron nano-particle resin Lewatit (FO36). Korean J Chem Eng 2012; 29(4): 4737. doi: 10.1007/s11814-011-0212-4.

38. Bani Najjar F. Removal of nitrate from drinking water sources using carbon granules coated with zero iron [dissertation]. Tehran: Payame Noor University of Tehran; 2015.

39. Cao D, Jin X, Gan L, Wang T, Chen Z. Removal of phosphate using iron oxide nanoparticles synthesized by eucalyptus leaf extract in the presence of CTAB surfactant. Chemosphere 2016; 159: 23-31. doi: 10.1016/j.chemosphere.2016.05.080.

40. Khodadadi M, Hosseinnejad A, Rafati L, Dorri H, Nasseh N. Removal of Phosphate from Aqueous Solutions by Iron Nano-Magnetic Particle Coated with Powder Activated Carbon. Journal of Health Sciences and Technology 2017; 1(1): 17-22. [In Persian]. 